\title{
Employing and Exploiting the Presumptions of Communication in Argumentation: An Application of Normative Pragmatics*
}

\author{
SCOTT JACOBS
}

Department of Communication

University of Illinois at Urbana-Champaign

3001 Lincoln Hall

702 S. Wright St.

Urbana, IL 61801

U.S.A.

csjacobs@illinois.edu

\begin{abstract}
Argumentation occurs through and as communicative activity. Communication (and therefore argumentation) is organized by pragmatic principles of expression and interpretation. Grice's theory of conversational implicature provides a model for how people use rational principles to manage how they reason to representations of arguments, and not just reason from those representations. These principles are systematic biases that make possible reasonable decision-making and intersubjective understandings, but also make possible errors and abuses. Much that is problematic in argumentation involves the ways the pragmatic principles of communication are exploited and the difficulties audiences and interlocutors have detecting and managing these abuses.
\end{abstract}

Résumé: L'argumentation se produit à travers et comme une activité communicative. La communication (et donc l'argumentation) est organisée par des principes pragmatiques d'expression et d'interprétation. La théorie de Grice des implicatures conversationnelles fournit un modèle de l'usage que les gens font des principes rationnels pour gérer la façon dont ils raisonnent en réaction envers des représentations d'arguments, et non pas seulement à partir de ces représentations. Ces principes sont des penchants systématiques qui rendent possible la prise de décision raisonnable et la compréhension intersubjective, mais qui font aussi des erreurs et des abus possibles. Beaucoup de ce qui est problématique dans l'argumentation implique les façons que les principes pragmatiques de la communication sont exploités et les difficultés que des auditoires et des interlocuteurs ont à détecter et à gérer ces abus.

Keywords: charity, deception, enthymemes, fallacies, implicature, informational aptness, informational sufficiency, necessity, normal forms, normative pragmatics

* A Keynote address at the OSSA11 Conference: Argumentation, Objectivity and Bias, University of Windsor, May 18-21, 2016.

(C) Scott Jacobs. Informal Logic, Vol. 36, No. 2 (2016), pp. 159-191. 
160 Scott Jacobs

\section{Introduction}

Determine the truth of a proposition according to the force of the better argument and the force of the better argument alone.

The Prime Directive of Argumentation

The Prime Directive of argumentation places the function of justification at the center of argumentation theory. ${ }^{2}$ This directive assumes that arguments do this job of justification, that one argument is objectively better than another, and that the process of argumentation, if conducted properly, will lead to the discovery of the better argument. All good so far, but argumentation theorists need to be careful when thinking this way. With this focus, it is easy to think of bias as a departure from ideal (unbiased) procedures, as distortion, limitation, and disability, as a matter of presence or absence. It is also easy to think of arguments as given, as the unproblematic starting point for analysis and assessment. Interpretation and representation are easily treated as something extrinsic to its object (the argument), as simply a source of error.

I don't think that's quite right. I don't think the problem with bias is its presence or absence, but its deployment. And I don't think arguments are just the objects of interpretation, but the achievements of communication. I want to show what profit can be had by looking at the relationship of bias and argumentation quality from the perspective of communication pragmatics. One central aspect of message design has to do with the ways in which the interpretation of argumentative messages is grounded in principles and biases that make communication possible in the first place. Those principles and biases are indispensible, but they are also vulnerable to systematic abuses.

Argumentation theorists tend to think of these abuses as fallacies. But they tend not to care much about how the kinds of abuses we associate with fallacies could go unrecognized. I think a lot of it has to do with some paradoxical features of how communication works. Bad arguments go unrecognized not just because people are bad reasoners. People can often recognize a

\footnotetext{
${ }^{1}$ Previous portions of this article appeared in Jacobs (2015).

2 By 'truth' I don't mean anything deeply metaphysical. I mean much the same as minimalist and deflationary accounts of truth (Horwich 1990). These accounts are consistent with but not committed to realism, antirealism, objectivism, contextualism, idealism, empiricism, correspondence theories, coherence theories, or pragmatist theories. Just because it is tough (even impossible) to tell whether or not any particular proposition is true shouldn't be a reason for argumentation scholars to deny that the truth of propositions is central to argument analysis, evaluation, and practice.
}

(C) Scott Jacobs. Informal Logic, Vol. 36, No. 2 (2016), pp. 159-191. 
fallacy once it is pointed out to them. That's why textbooks use clear-cut examples of fallacies: They are obviously fallacious. But most real-life fallacies don't work if they are recognized for what they are. So they have to go unrecognized as such. And I think how fallacies do this often has to do with systematic principles of message design - the very principles that make messages intelligible and recognizable in the first place.

Many fallacies work because of the way in which arguers take advantage of the interpretive practices of audiences. Many tactics are tricky, deceptive, and otherwise fraudulent because of the way in which the construction of messages relies upon the charitable application of pragmatic principles of message design. Charity is a bias we cannot live without - but there are risks and costs that follow from those biases. The risks of faulty arguments and other bad moves are built into the very ways in which arguers try to fulfill the prime directive and accomplish reasonable argumentation.

Many verbal scams and swindles come off by expressing conversational implicatures - or at least by encouraging hearers to assume that a conversational implicature is there to be found. H. P. Grice (1975/1989) first introduced the idea of conversational implicature in his 1967 William James lectures. Grice's fundamental insight was that the communication of messages was a rational enterprise. In expressing and interpreting a message, people go beyond the information that is given alone by the conventions of syntax and semantics. People go beyond the information given by constructing a context of assumptions and inferences that make sense of what was said and of what was not said but could have been said, and that make sense of how and when all of it was said. Words and sentences themselves are not the message by which arguments are conveyed. Words and sentences are cues for constructing the message. The message is this assemblage of assumptions and inferences. And in looking for a message that makes sense, for Grice at least, "makes sense" means something like "satisfies standards for rational action." So, when Grice called attention to conversational implicatures, he was calling attention to something that ought to be of special interest to argumentation scholars.

A conversational implicature can be thought of as:

Inferences to those unarticulated attitudes, beliefs, and intentions that make what is said and done, in the way that it is said and done, when it is said and done, a rational means to convey a message. 


\section{Scott Jacobs}

If this formulation is too much of a mouthful, just follow the highlighted words to get the gist. ${ }^{3}$ For argumentation scholars, Grice was showing how the ways in which people reason to representations of arguments is just as much subject to rational norms as is the way in which people reason from or with representations of arguments. ${ }^{4}$

The pragmatic principles of communication that generate implicatures are exemplified by Grice's (1989) Cooperative Principle and by its attendant Conversational Maxims. The Cooperative Principle (CP) states:

Make your conversational contribution such as is required, at the stage at which it occurs, by the accepted purpose or direction of the talk exchange in which you are engaged. (Grice 1989, p. 26)

The conversational maxims can be thought of as standards for message construction to which speaker and hearer mutually attend. ${ }^{5}$ Communicators reciprocally presume the applicability of the following norms for fashioning and figuring out the message:

\footnotetext{
${ }^{3}$ My definition of conversational implicature overlooks important distinctions among implicature, explicature (Carston 1988), impliciture (Bach 1944), accommodation (Lewis 1979) and other kinds of pragmatic enrichment (Recanati 2012). For our purposes, the important point is that all these will be subject to Gricean principles of rational interpretation.

${ }^{4}$ I thank Michael van Lambalgan for this felicitous formulation.

${ }^{5}$ While the CP is frequently interpreted as calling for helpful behavior, the principle is primarily a call for rational conduct under conditions of interdependence (see van Eemeren, Grootendorst, Jackson \& Jacobs 1993, pp. 611). Cooperation may be strongly presumed for information exchange, but does not extend in the same way to other aspects of social activity. The $2^{\text {nd }}-$ order "we-ness" of communicative activity still forms a frame around other, uncooperative activities such as hostile cross-examination in court (Jacobs \& Jackson 2006), persuasive advertising (Jacobs 1995) or partisan political advocacy (Jacobs 2016). This is why Grice $(1975$, p. 48) entertained but ultimately rejected a "quasi-contractual" analysis of the $\mathrm{CP}$, since such an analysis would not encompass uncooperative exchanges like quarrels. Messages in even these contexts are constructed so as to generate implicatures that save the normative applicability of the $\mathrm{CP}$ despite strong hearer suspicions that they are being hoodwinked. Brown and Levinson $(1987$, p. 5) astutely point out that this presumption of communicative cooperation is far more basic than, say, the presumption of politeness. One hears and sees impoliteness quite readily. It is really quite difficult not to search for the sense, relevance, truthfulness, and informativeness of an utterance unless openly signalled to suspend such presumptions.
}

(C) Scott Jacobs. Informal Logic, Vol. 36, No. 2 (2016), pp. 159-191. 
Quantity:

-Be as informative as is required (for the current purposes of the exchange).

-Do not be more informative than is required.

Quality: Try to make your contribution one that is true.

-Do not say what you believe to be false.

-Do not say that for which you lack adequate evidence.

Relation: Be relevant.

Manner: Be perspicuous.

-Avoid obscurity of expression.

-Avoid ambiguity.

- Be brief (avoid unnecessary prolixity).

-Be orderly.

But there are many other formulations. Sperber and Wilson's (1995) Presumption of Optimal Relevance emphasizes the expectation of efficiency in communication (maximum information utility; minimum processing cost), which is something Grice leaves implicit. ${ }^{6}$ Horn's (1984) R- and Q-Principles ${ }^{7}$ find in Grice's maxims a division of labor or negotiated equilibrium between speaker and hearer based on something like Zipf's (1949) Principle of Least Effort: Do what one must, but no more than one has to. Levinson's (2000) Q-, M-, and I-Principles call attention to the central role of stereotypical knowledge and (ab)normal means of expression in making inferences. ${ }^{8}$ He pro-

${ }^{6}$ The ostensive stimulus is relevant enough for it to be worth the addressee's effort to process it. The ostensive stimulus is the most relevant one compatible with the communicator's abilities and preferences.

${ }^{7}$ The Q[uantity]-Principle (Hearer-based):

- Make your contribution sufficient

- Say as much as you can (given R)

The R[elevance]-Principle (Speaker-based):

- Make your contribution necessary

- Say no more than you must (given Q)

${ }^{8}$ Q-Principle: What isn't said, isn't. (What you do not say is not the case.) Speaker's maxim. Do not provide a statement that is informationally weaker than your knowledge of the world allows.

Recipient corollary. Take it that the speaker made the strongest statement consistent with what he knows.

M-Principle: What's said in an abnormal way isn't normal.

Speaker's maxim. Indicate an abnormal, non-stereotypical situation by using marked expressions that contrast with those you would use to describe the corresponding normal, stereotypical situations.

Recipient corollary. What is said in an abnormal way indicates an abnormal situation.

I-Principle: What is expressed simply is stereotypically exemplified. Speaker's maxim. Produce the minimal linguistic information sufficient to achieve your communicational ends.

(C) Scott Jacobs. Informal Logic, Vol. 36, No. 2 (2016), pp. 159-191. 


\section{Scott Jacobs}

posed these principles to account for generalized conversational implicatures (default-type interpretations), but they also readily apply to particularized conversational implicatures (contextspecific interpretations).

I am not particularly concerned with exactly which formulation of rational standards for communication one prefers to use. All have their advantages. All can be fleshed out to provide more specific principles. And none are so precise, consistent or complete as to allow exact and unequivocal specification of particular implicatures. All the available formulations depend upon prior and independent natural language user intuitions to drive any analysis. ${ }^{9}$

Grice's system has the nice feature of isolating expectations of truthfulness, informativeness, relevance, and perspicuity, all with respect to purpose. These are interpretive standards that fit well with the interests and norms of argumentation theorists. Apply them to the purpose of justifying a claim, and out falls something very much like, say, Johnson and Blair's (1994) standards of premise acceptability, sufficiency, and relevance. And the presumption that the speaker is observing the Cooperative Principle and Conversational Maxims - or is at least trying to satisfy them as best as is feasible - amounts to what argumentation scholars will recognize as the kind of charity principle that guides analytic reconstructions of arguments (van Eemeren 1987, pp. 210-11;

Recipient corollary. Amplify the informational content of the speaker's utterance, by finding the most specific interpretation consistent with stereotypical knowledge, up to what you judge to be the speaker's point.

${ }^{9}$ While Grice (1975, p. 50) insists that hearers can "work out" conversational implicatures using the $\mathrm{CP}$ and its maxims, this will be a decidedly underdetermined and post hoc rationalization. It is neither generative nor demonstrative in any formal or even quasi-formal way. To work out an implicature, the hearer sees:

He has said that $p$; there is no reason to suppose that he is not observing the maxims, or at least the $\mathrm{CP}$; he could not be doing this unless he thought that $q$; he knows (and know that I know that he knows) that I can see that the supposition that he thinks that $q$ IS required; he has done nothing to stop me thinking that $q$; he intends me to think, or is at least willing to allow me to think, that $q$; and so he has implicated that $q$.

Grice's maxims suggest standards by which implicatures can be tested, but this framework cannot generate the candidate implicatures. Nor can it suggest how anyone can see what can and cannot be reasonably expected or commonly understood. Neither can it demonstrate what is or is not required by the CP or maxims. So, to say that implicatures are "calculable" in any practical sense according to such principles is simply false (cf. Davis 1998). An analyst can no more find in Grice a mechanical interpretive procedure than can a computer program (Frederking 1996).

(C) Scott Jacobs. Informal Logic, Vol. 36, No. 2 (2016), pp. 159-191. 
Govier 2013, pp. 51-52; Johnson 1981; Johnson \& Blair 1994, pp. 15-16; Scriven 1976, pp. 71-73; Thomas 1977, p. 9; 1991, p. 60; Woods 2004, pp. 219-238). ${ }^{10}$ The difference is that Grice's Cooperative Principle is not a methodological principle for cleaning up meanings that seem ambiguous, vague, or indeterminate; it is a principle whereby those qualities are fixed into the discourse in the first place. The principle does not go beyond or compensate for the intuitions we have as natural language users, though it is perfectly plausible according to Grice that hearers miss what is implicated, or mistakenly hear as meant implicatures that were not meant, or that speakers fail to effectively convey the meanings they intend or just those meanings they intend. Generating implicatures is an intrinsically fallible business for all parties.

Now, the idea that I want to pursue with respect to verbal tricks, swindles, frauds, and the like is this: The same standards that make communication possible in the first place also make deceptions and verbal frauds possible. Deceptions and swindles can exploit these presumptions in pernicious ways. In making those presumptions, people can be led to infer information that is false. People can be led to draw conclusions that are unjustified. And people can be led to simply overlook messages that are fraudulent. Indeed, I would venture to say that a great many fallacies succeed and go unnoticed by exploiting the general presumptions on the part of an audience that discourse conveys what is true and justified, informative, and useful enough for the apparent purposes in play. The biases of interpretation work in such a way that if a satisfying interpretation can be found, and nothing has been signaled that you shouldn't make that interpretation, then you should go ahead and make it.

\section{Playing the Willie Horton card}

Ambiguity is one place where devious arguers can exploit the pragmatic biases that make communication work in the first place. Argumentation theorists by and large have considered ambiguity to be a problem of determinateness or consistency in inference. When terms are ambiguous, vague, equivocal, or otherwise multiple in possible meaning, inferences cannot be drawn reliably. But ambiguity is more than just a logical problem or a coordination problem due to miscommunication (cf., van Eemeren

${ }^{10}$ As a theoretical rather than methodological principle, Davidson (1973a, 1973b, 1974) and Lewis (1974) discuss a charity principle, seeing it as a precondition for any interpretation at all. Schutz's (1962, pp. 11-13; Schutz \& Luckmann 1989, p. 209) reciprocity of perspectives assumption does a similar work.

(C) Scott Jacobs. Informal Logic, Vol. 36, No. 2 (2016), pp. 159-191. 


\section{Scott Jacobs}

\& Grootendorst 1992, chap. 18; Walton 2000). The vast bulk of ambiguities never rise to the level of notice because people naturally settle on those meanings which best fit Gricean maxims (Akmajian, Demers, Farmer \& Harnish 2010, pp. 368-369). But such unnoticed ambiguities are subject to exploitation. Fallacies of ambiguity can have a pragmatic dimension that trades on the way in which two interpretations are laid out. One interpretation has relatively benign content. The interpretation is true, but not of much argumentative relevance. The other interpretation would be a strong argument, if only its content were true. But there's the rub. The audience presumes truth, is biased to assume it unless in some way they are flagged off, and so the audience goes ahead and selects that interpretation which is most relevant to the manifest purposes of the arguer. And in the case of this sort of fallacy, the content of that interpretation proves not to be true, and the audience is misled.

For example, consider a card distributed on university campuses by the College Republican National Committee on behalf of the George H. W. Bush 1988 presidential election campaign.

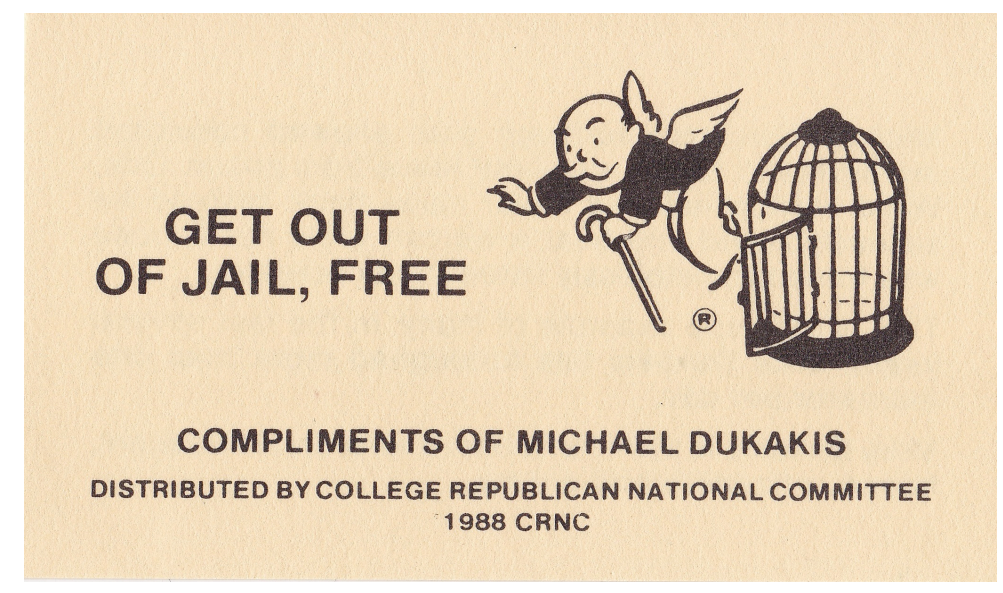

Figure 1. "Get Out of Jail, Free" card, front

The front of the yellow card looks like a well-known card in the game of Monopoly - a "Get Out of Jail Free" card (see Figure 1). In the game of Monopoly, there is a square on the game board known as Jail. Players who land on that square cannot take their turn for three rounds without paying a penalty. But if a player has drawn this card, they can play the card to take their turn without paying a penalty.

On the back of the card one finds the now notorious story of Willie Horton (see Figure 2). The story had been widely broadcast 
on TV campaign ads and was the subject of numerous news reports. ${ }^{11}$ Willie Horton was a black prisoner sentenced to life in prison for murder (as it happens, of a white man). He was released on furlough by the state of Massachusetts during Michael Dukakis's term as governor. As the card suggests, Willie Horton got out of jail free.

Michael Dukakis's furlough plan allowed convicted murderers to take a weekend leave from prison. One, Willie Horton left and never came back. Instead he viciously raped and beat a woman while her fiancée was forced to helplessly listen to her screams.

This is only one example of many. In the last several years, Mike Dukakis has furloughed more than one murderer per day.

Mike Dukakis is the killer's best friend, and the decent, honest citizens' worst enemy.

Figure 2. "Get Out of Jail, Free" card, back.

The ambiguity in the card comes in the sentence, "This is only one example of many."

One might ask, of many what? One example of convicted murderers who were allowed to take a weekend leave? Or is it only one example out of many convicted murderers who on their weekend leave committed a heinous crime like viciously raping and beating a woman while her fiancée was forced to helplessly listen to her screams? The first interpretation provides little support for the presumed purpose of card: to show that Michael Dukakis is not fit to serve as President of the United States of America and should not be voted for. On the first interpretation the information is so weak as to be almost irrelevant-or even counterproductive. After all, presumably a large number of such furloughs were given, and if this was only one case among many furloughs, then what Willie Horton did could be seen as an aberrant exception to the rule.

\footnotetext{
${ }^{11}$ See Simon (1990) for an in-depth story behind the Bush campaign's use of the Willie Horton issue. Both the initial campaign ad, "Bush and Dukakis on Crime," distributed by the conservative National Security Political Action Committee (1988a) and the follow-up ad, "Revolving Door," distributed by the Bush-Quayle '88 Presidential Election Committee (1988) can be seen on YouTube. Jamieson (1992, pp. 15-42, 221) and Mendelberg (2001, pp. 134190) provide illuminating analyses of how the implicit race appeals in the ads moved voters.
} 
But the second interpretation magnifies severalfold one of middle-class white America's worst nightmares. (The woman and her fiancée, it turns out, were both white, and that seems to be implicated for many white Americans who knew that Willie Horton was African-American.) ${ }^{12}$ The second interpretation would surely provide many of these voters with a strong reason to conclude that Michael Dukakis is unfit to serve as President of the United States of America (i.e., as Protector-in-Chief). And this latter interpretation of the message would be warranted by simply presuming that the information that the College Republican National Committee conveys is relevant and sufficient to achieve the obvious purpose of advocating the election of George $\mathrm{H}$. W. Bush, just as Grice's conversational maxims call for.

However, there's a problem. This stronger interpretation would also implicate information that is false. No other convicted murderer released on furlough committed any crime remotely approaching what Willie Horton did. But, of course, the Bush campaign is gambling that the otherwise uninformed voter would not know this. And they are exploiting the possible existence of the benign if irrelevant interpretation in order to avoid accountability should they be challenged. They leave themselves with a measure of plausible deniability: They just meant that Michael Dukakis had overseen a program that released many prisoners on furlough. And that was wrong to do. Implicatures are, after all, fallible inferences. Mistakes happen. And so the fallacy slips by. ${ }^{13}$

12 The National Security Political Action Committee (1988b) broadcast a follow-up TV ad featuring the fiancée attacked by Horton, Cliff Barnes. The talking head close-up makes obvious his race (and by implicature, the race of the woman raped by Horton).

${ }^{13}$ One might still wonder if the ambiguity was, after all, just an innocent mistake. No such ambiguity exists in the initial ad, "Bush and Dukakis on Crime." [Narrator: "Bush and Dukakis on crime. Bush supports the death penalty for first-degree murderers. Dukakis not only opposes the death penalty, he allowed first-degree murderers to have weekend passes from prison. One was Willie Horton, who murdered a boy in a robbery, stabbing him nineteen times. Despite a life sentence, Horton received ten weekend passes from prison. Horton fled, kidnapped a young couple, stabbing the man, and repeatedly raping his girlfriend. Weekend prison passes. Dukakis on crime."] However, the follow-up ad, "Revolving Door," does contain a very similar phrase, here highlighted. [Narrator: "As governor, Michael Dukakis vetoed mandatory sentences for drug dealers. He vetoed the death penalty. His revolving door prison policy gave weekend furloughs to first-degree murderers not eligible for parole. While out, many committed other crimes like kidnapping and rape. And many are still at large. Now Michael Dukakis says he wants to do for America what he's done for Massachusetts. America can't afford that risk."] During this highlighted phrase, the screen also shows "268 Escaped" as though to call attention to what the narrator is saying and to suggest that 
But ambiguity resolution is not the only place in this card where interpretive principles are abused. Notice also how the card abuses what Stephen Levinson (2000) calls the I-Principle and the M-Principle:

I-Principle: What is expressed simply is stereotypically exemplified.

M-Principle: What is said in an abnormal way, isn't normal.

Levinson (2000) takes his principles to be pragmatic meaning heuristics that reformulate Grice's Quantity and Manner maxims. The I-Principle is what allows people to fill-in information left unsaid on the Gricean assumption that the speaker is saying no more than is needed. It entitles hearers to do the kind of interpretive work that Levinson (2000) formulates as a Recipient Corollary:

I-Principle Recipient Corollary: Amplify the informational content of the speaker's utterance, by finding the most specific interpretation consistent with stereotypical knowledge, up to what you judge to be the speaker's point.

The M-Principle, in complementary fashion, obligates speakers to do the kind of expressive work that Levinson (2000) calls a Speaker's Maxim:

M-Principle Speaker's Maxim: Indicate an abnormal, non-stereotypical situation by using marked expressions that contrast with those you would use to describe the corresponding normal, stereotypical situations.

Taken together, these two principles warrant hearers making a kind of "Normal Forms" assumption (following Cicourel 1970: 35, 53; and Schutz 1962: 15-26).

Normal Forms: What is said represents ordinary meanings, ordinary usages, and ordinary circumstances unless told otherwise

We assume ordinary meanings and apply ordinary knowledge ("what everyone knows") to the words and phrases used on the

"many" is 268 . Here the ambiguity also arises as to how many times upon escape the crimes of kidnapping and rape were committed.

(C) Scott Jacobs. Informal Logic, Vol. 36, No. 2 (2016), pp. 159-191. 


\section{Scott Jacobs}

expectation that if important features of social typifications did not hold, the speaker would flag us off from assuming so.

Now, how does all this apply to the card? Look at the phrase, "Dukakis's furlough plan." That phrase would ordinarily suggest that the program was planned and initiated by Dukakis. This is not a necessary aspect of the literal meaning of the phrase, but it would be the typical, normal state of affairs indicated by use of the possessive and maybe also by special connotations of agency and action associated with the nominalized verb, "plan" (as opposed to "program"). If we hear this information in use of the phrase, we are hearing implicatures.

The literal meaning of the phrase is true enough as far as it goes. And it is true that, after the Horton tragedy, Governor Dukakis resisted revoking the furlough program for prisoners sentenced to life in prison. But the furlough program was in fact planned and signed into law by the previous governor, who was a Republican. Moreover, the legislation for the furlough program was based on a furlough plan introduced by the governor of a different state: Governor Ronald Reagan of California (the man under whose presidency George Bush was currently serving as Vice-President).

It is easy to see here some sort of abuse going on. Part of that abuse is a devious exploitation of the reader's bias toward assuming normal forms based on Levinson's heuristics. Given that the presumed purpose of the card is to blame Dukakis for the consequences of the furlough program, it would be perfectly consistent to infer that Dukakis bore special responsibility for its creation, and not just failure of responsibility to end a program already underway. That must be the point of the card introducing and formulating the phrase in the way presented, one would think. The card seems to be inviting the reader to think that Dukakis was inventor and initiator and not just administrator. This information would be normal and stereotypical, and consistent with the purpose of the card. So, a reader fills it in. But to draw that implicature would be to draw something false.

Our intuitions of abuse, however, go beyond just a sense that our assumption of typifications has led us astray. Our sense of abuse also comes from our understanding that the phrase used is not the best available phrasing. There is a tacit confidence that alternative expressions could have been used but weren't (e.g., "While Michael Dukakis was governor of Massachusetts, the state's furlough plan allowed..." or "The furlough program continued by Michael Dukakis allowed..."). "Best" available phrasing here goes beyond just the truth of the literal meaning. All the phrases are literally true. What matters is not if what is said is the truth, but if what is conveyed is the truth, the whole truth, and 
nothing but the truth, as far as is feasible, for the purposes of the exchange. Responsible advocates are expected to respect this dictum. Another way to put this idea is in terms of what I will call a Principle of Informational Aptness:

Informational Aptness: The labels used are the most apt descriptions relative to other available descriptions, i.e., the labels used activate the greatest number of true and relevant implicatures and the least number of false or irrelevant implicatures.

Part of what makes using the phrase, "Dukakis's furlough plan," improper is our implicit trust in the speaker observing something like this principle. We expect wording to be apt in the sense that we expect to pour in typifications to fit the purposes of the exchange and the resultant implicatures to fit this standard.

But it is not just presumptions of aptness and normal forms that are a work here. Part of the abuse is also the reader's assumption that, in Gricean terms, the arguer is being as informative as is necessary. A presumption of aptness and (just) the applicability of normal forms imply that any information not conveyed is not needed. That's why, when we learn of the kind of extra information reported above, we feel that we've been hoodwinked. Surely the College Republican National Committee knew all this information, knew it would affect how the situation would be understood, and knew that an ordinary reader would not know this. We've been swindled because we have a bias to assume that the arguer is respecting something like the following pragmatic principle. Call it a Principle of Informational Necessity and Sufficiency:

Informational Necessity \& Sufficiency: What is true but left unmentioned, and cannot be ordinarily inferred, must not be relevant to the purposes of the exchange (or must not be known by the speaker to be true, relevant and/or uninferrable). What was mentioned must be informationally sufficient for the purposes of the exchange.

The presumption goes that if something was not mentioned, it must not be important; it must not have been needed to accurately capture the nature of the situation for the purposes at hand. And so, by default, whatever was mentioned must be informationally sufficient for the purposes of the message. If the speaker thought otherwise, the speaker would flag us off from acting on that assumption. Presumably, the purpose for the reader is to decide the blameworthiness of Dukakis concerning the furlough of Willie Horton with respect to who to vote for in the Presidential election, 
all this based on an assessment of the objectively true and relevant facts of the matter. At the very least, once all this additional information is made apparent it becomes rather clear that the purposes of the arguer (the College Republican National Committee) are not in line with the purposes of the reader, and that the arguer's purposes are being fulfilled by subverting the reader's purpose and keeping that misalignment of purpose concealed.

\section{Vice-President Cheney on secret military tribunals}

But fallacies that exploit an audience's bias toward presuming relevance and informative sufficiency can work without keeping relevant information hidden. Sometimes this kind of abuse can occur even when everything is more or less out in the open. Consider how enthymemes work. The standard account given for enthymemes is that they are incomplete syllogisms with an unstated premise or conclusion that is filled-in by the audience. Logicians have long emphasized the structural incompleteness (Copi 1953, pp. 204-207); rhetorical scholars since Bitzer (1959) have emphasized the work of the audience. No doubt this captures some enthymemes, especially those where the conclusion is what goes unstated. But there is another way to think about an enthymeme. Enthymemes can be thought of pragmatically as arguments whose inferential adequacy or point has not been cast in doubt. Enthymemes are arguments where it is simply presumed that satisfactory components could be offered if called for (Jackson \& Jacobs 1980). This presumption amounts to a kind of charitable benefit of the doubt.

People generally do make arguments that can be "filledin" if called on to do so. At least, they can do it for those simple syllogistic steps that may not be all that informative but do satisfy formal demands. If they can't save the argument for themselves, then a trained academic generally can see how to do it. And humans do have active and workable reflective imaginations. No doubt, people often consciously see what the missing premise or conclusion of an argument should be. But how often they actually see it before they are asked to provide it is not at all clear.

Consider an argument reported in the New York Times shortly after the 9-11 attacks (Buhmiller \& Myers 2001). Entitled, "Senior Administration Officials Defend Military Tribunals for Terrorist Suspects," the article reports VicePresident Dick Cheney making an argument defending a presidential order authorizing secret military tribunals to try 
foreigners charged with terrorism. Defense of the presidential order is announced in the first paragraph of the article. The middle four paragraphs then develop the nature of the presidential order for secret military tribunals and ends with a challenge to the extraordinary procedure. The final four paragraphs of the story supply Cheney's argument in defense of the military tribunals:

Top administration officials today defended a presidential order allowing military tribunals to try foreigners charged with terrorism as the Pentagon prepared for the potential transfer of immigrants detained by the Justice Department into military custody.

A senior administration official said that it was possible that immigrants held in the United States by the Justice Department in connection with the Sept. 11 attacks would be tried by military tribunal. Those trials could take place outside the United States or even on ships, the official said.

The order, signed by President Bush on Tuesday, gives the government sweeping powers to secretly and aggressively prosecute suspected foreign terrorists both here and abroad.

Justice Department officials have repeatedly refused to disclose the identities of those immigrants held or the charges against them. Justice officials said late last month that the total number of people detained -- including many who have since been released -- had surpassed 1,000 , but this month officials said that they would no longer release a running tally.

"I had no idea they were going to try to use it for domestically detained people," said Kevin Ernst, a Detroit lawyer representing Farouk Ali-Hamoud, who was arrested for fraudulent immigration documents and held for 25 days in the Wayne County Jail before his case was dismissed last month. "It scares the hell out of me, I'll tell you that."

Vice President Dick Cheney defended Mr. Bush's order today, saying that terrorists were not lawful combatants and did not deserve the safeguards of traditional American jurisprudence.

"The basic proposition here is that somebody who comes into the United States of America illegally, who conducts a terrorist operation killing thousands of innocent Ameri- 
cans - men, women and children - is not a lawful combatant," Mr. Cheney said.

"They don't deserve to be treated as a prisoner of war," he added. "They don't deserve the same guarantees and safeguards that would be used for an American citizen going through the normal judicial process."

While the vice president assured his audience that the terrorist suspects would have "a fair trial," he suggested that they did not deserve one with the same protections afforded American citizens. A military tribunal, he said, "guarantees that we'll have the kind of treatment of these individuals that we believe they deserve."

The claim or conclusion seems clear enough. The claim denies an assumption behind the complaint lodged against the secret military tribunals for foreigners charged with terrorism. Put it this way: Foreigners charged as terrorists are people who do not deserve traditional judicial protections. And the reason in support of this claim also seems pretty straightforward: Terrorists are people who do not deserve traditional judicial protections. So that's the argument:

\section{Claim:}

Foreigners charged as terrorists are people who do not deserve traditional judicial protections

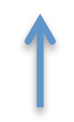

\section{Reason:}

Terrorists are people who do not deserve traditional judicial protections.

There is a real problem here. How did Cheney get to that conclusion from that reason? What missing premise could be assumed? There is a missing premise that would make the argument into a valid syllogism, but it is not a premise that many people would find acceptable should they take the trouble to spell it out. To see what that premise must be, just cut up Cheney's argument into three categories: Let $\boldsymbol{F}$ stand for "foreigners charged as terrorists". Let $\boldsymbol{J}$ stand for "people who deserve judicial protections". Let $\boldsymbol{T}$ be"terrorists". Apply that to Cheney's reason and conclusion and we get the following incomplete form:

\section{No $\boldsymbol{T}$ are $\boldsymbol{J}$}

\section{$? ?$}

$\therefore$ No $\boldsymbol{F}$ are $\boldsymbol{J}$ 
So what's the missing premise? Once you put it this way, the missing premise is pretty easy to see. It can't be All $\boldsymbol{T}$ are $\boldsymbol{F}$. That argument would be a real howler. Besides, the Department of Homeland Security is not anywhere near good enough for even Dick Cheney to have thought that all the terrorists had been caught and charged.

Maybe it is the weaker claim that some terrorists have been caught, that some terrorists are foreigners charged as terrorists (Some $\boldsymbol{T}$ are $\boldsymbol{F}$ )? Notice that this is the same as saying that some foreigners charged as terrorists are terrorists (Some $\boldsymbol{F}$ are $\boldsymbol{T}$ ). It does seem plausible to think that Cheney would believe this and would also expect his audience to believe this. But that premise still builds a howler. You can't get from those premises to the desired conclusion in defence of secret military tribunals - that no foreigners charged as terrorists are people who deserve judicial protections.

One could go back and try revising the conclusion: Some foreigners charged as terrorists are not people who deserve judicial protections (Some $\boldsymbol{F}$ are not $\boldsymbol{J}$ ). That conclusion does logically follow from these two premises. And one might think that is the charitable way to make sense of Cheney's argument. But there is a problem here. Now the conclusion no longer refutes the complaints against secret military tribunals for foreigners charged with terrorism. To say that some foreigners charged with terrorism do not deserve judicial protections (Some $\boldsymbol{F}$ are not $\boldsymbol{J}$ ) does not exclude the possibility that some foreigners charged with terrorism do deserve judicial protections (Some $\boldsymbol{F}$ are $\boldsymbol{J}$ ). Maybe some Canadians, for example.

Likewise, even if we accept that some terrorists have been caught and are foreigners charged as terrorists (Some $\boldsymbol{T}$ are $\boldsymbol{F}$ ), that does not exclude the possibility that some of the foreigners who have been charged with terrorism are not terrorists (Some $\boldsymbol{F}$ are not $\boldsymbol{T}$ ). And properly determining who is and who is not a terrorist is, after all, the whole point of judicial protections. We want to make sure that the innocent are not treated unjustly, and to do that we have to provide the same treatment to the guilty because we cannot determine in advance of the judicial procedure who is who.

So what's left? It has to be: All $\boldsymbol{F}$ are $\boldsymbol{T}$. All foreigners charged as terrorists are terrorists.

\section{No $\boldsymbol{T}$ are $\boldsymbol{J}$ \\ $\underline{\text { All } \boldsymbol{F} \text { are } \boldsymbol{T}}$ \\ $\therefore$ No $\boldsymbol{F}$ are $\boldsymbol{J}$}




\section{Scott Jacobs}

That's the only premise that forms a logical link. ${ }^{14}$ And that's the problem with Cheney's argument.

Talk about pre-judgment. This argument begs the question. And it does so in a pretty serious way. It smuggles in by assumption a premise whose determination is the point at issue in judicial proceedings. Whether or not someone charged with terrorism is in fact a terrorist is something that judicial proceedings are supposed to decide. That is why there was the objection to military tribunals replacing judicial proceedings. But people who don't look closely at Cheney's argument and just presume that relevant, true and sufficient premises could be provided if called for, are liable to miss that the argument ignores or presumes the truth of exactly what needs to be proven.

\section{Responding to 60 Minutes}

A similar betrayal of trust can be seen in the nature of "answerhood" in question-answer dialogue. Even more so than with enthymemes, responsiveness would seem to be something more or less out in the open, readily available for inspection and notice by any natural language user. Yet that is not always the case. Consider the front page of a three-page fact sheet I received while working at the University of Arizona (Office of the President 1995). The memo was distributed on Office of the President, University of Arizona letterhead to local news outlets and to departments on the campus, together with a letter from President Manuel T. Pacheco.

The memo and letter came in response to an exposé on college education in America entitled, "Get Real," by the television news show, 60 Minutes (Stahl 1995). The news show

\footnotetext{
${ }^{14}$ Since the claim is that the premise added to an enthymeme is implicated but not logically implied, context might allow other lines of reasoning in interpreting Cheney's argument. We have, for example, presumed a deductive pattern of syllogistic logic. Nor can we rule out that the Times misreported or otherwise represented the sense of Cheney's argument in some important way. We have only the argument as given in the text of the story. However, one could argue that, in the apparent absence of any additional contextual resources, any more complex or less determinate argument is not obvious, nor is it somehow signalled. Some such argument might better satisfy standards of truth, informativeness, and relevance, but it would still never get off the ground without some kind of special cues and is at best a poorly communicated argument that violates Grice's Manner Maxim or Sperber \& Wilson's (1995) Presumption of Optimal Relevance. On the pragmatics of unexpressed premise also see van Eemeren \& Grootendorst (1982; 1983; \& 1984, pp. 119149).
}

(C) Scott Jacobs. Informal Logic, Vol. 36, No. 2 (2016), pp. 159-191. 
prominently featured classes at the University of Arizona, and the memo was designed to refute many of the claims the show made about what was going on at the University of Arizona. ${ }^{15}$ Of particular interest is the answer to the third question, "Does the English department really have no professors teaching freshman composition?" (See Figure 3).

One might think that what is going on is a kind of indirect answer, the kind of answer that takes some additional inferential work to figure out because the person giving the answer has some reason not to just simply and straightforwardly answer the question. In Gricean terms, with indirect answers you often find some kind of clash among the maxims, between say, the obligation to be appropriately informative and the obligation to be perspicuous or the obligation to be truthful and not mislead and the obligation to be perspicuous. For example, perhaps the answer needs to be contextualized with additional information in order to avoid false inferences that would otherwise be made or to invite relevant inferences that would otherwise not be drawn. You still get the answer, but it comes at the cost of this extra inferential work. Indirect answers can be slippery by virtue of implicating false information in such a way that the speaker may avoid accountability, if only in the lame sense of being able to claim that they did not tell an out-and-out lie. After all, nothing that was simply said, literally and directly, was false. Only what was implicated was false, and implicatures are always defeasible and thereby deniable. ${ }^{16}$

\section{Quick Response to 60 MINUTES}

The 60 Minutes program about universities in general and The University of Arizona in particular gives us one good opportunity: It gives us a chance to talk about undergraduate education. Here are responses to several tough questions or comments that have come up a number of times.

Q. 60 Minutes said that parents are paying $\$ 15,000$ in tuition to subsidize research by professors. Is that true?

A. It's false. The program confused the University of Arizona and the situation at some small private universities. In-state tuition at the University is $\$ 1,800$, not $\$ 15,000$. Furthermore tuition dollars are never used to support research, period. Indeed the reverse is true because, $80 \%$

\footnotetext{
${ }^{15}$ For an interesting analysis of the real agenda behind the newscast, see Kolodny (1996).

${ }^{16}$ For Gricean analysis of misleading indirect answers in a legal context, see Jacobs \& Jackson (2006) and Tiersma (1990).
}

(C) Scott Jacobs. Informal Logic, Vol. 36, No. 2 (2016), pp. 159-191. 


\section{Scott Jacobs}

of the equipment used by undergraduate Science students was paid for by research grants.

Q: Is it true that $87 \%$ of freshmen are taught by Teaching Assistants?

A. It's false. 60 Minutes abused the statistics. If a master professor taught a three-hours per week class with 200 students, that counted as one. If he broke his class into nine one-hour lab groups, each led by a TA, each group counted as one. So 60 Minutes concluded that $90 \%$ of the sections are taught by Teaching Assistants. The fact is that from a student's viewpoint, the Teaching Assistant taught only 25 percent of the course. The majority of our lectures are taught by professors.

Q. Does the English department really have no professors teaching freshman composition?

A. Forty faculty members teach freshman composition. Some of them have been faculty elsewhere, and came back to the UA to do more advanced course work; some are part-time faculty in our own university. More to the point is the fact that, regardless of who teaches basic composition skills, our composition program is regarded as a model. Just one week before the 60 Minutes program, an article in the Chronicle of Higher Education cited parts of our program as a model for connecting teaching and research in the classroom

\section{Office of the President, University of Arizona, Memo}

Figure 3.

The answer to the third question in the University of Arizona memo illustrates a different kind of abuse than promoting the kind of false implicatures to which indirect answers are vulnerable. Indirect answers work by signaling to the interpreter that, if you want to get the answer, you're going to have to work for it. But if you work for it, you'll find it. Of course, anyone who has ever taught student readers knows that not everyone chooses to do that work. And that is where the abuse comes for the kind of answer we get to the third question in this memo.

In fact, the "answer" is not really an answer at all, although superficially it looks like one. It is really a case of an evasion (Polcar \& Jacobs 1998). It looks like an answer, albeit a very indirect answer. But there really is no indirect answer at all. A response is formulated that, on the face of it, looks enough like an indirect answer that one can presume it to be so. But if one tries to pin down just what the answer is, it can't be found. It eludes 
determination and then slips away (in the case, through a topic shift). And it takes careful reading to see that this is the case.

A careful reader might notice that, unlike the answers to the first two questions, a direct straightforward denial to the third question is suspiciously absent from the start of this answer. There is no "It's false."

Moreover, the categories contained in the answer do not really match the category contained in the question. The question asks whether or not any "professors" teach freshman composition. Most people would assume, I think, that the term "professors" is intended to refer to the ordinary, prototypical members of this category-tenure-stream faculty members; full, associate and assistant professors. That is the "normal form" for the category of professor in the United States. And it is the membership of this category that is at issue in the 60 Minutes exposé. But notice that the answer refers to the category of "faculty" who teach freshman composition. Just who are those forty "faculty members"?

We are told that "some" of them are individuals who "came back to the UA to do more advanced course work." Those must be graduate students, since professors do not take courses; they only teach them. "Some," we are told, are "part-time faculty." Those kind of faculty are called lecturers or adjunct professors in the United States, and they are not professors in the ordinary sense either. Either category might include individuals who were professors, but they are not very common, and in any case, they are not necessary members of either category. ${ }^{17}$ From this information, we are still unable to determine whether or not anyone remaining in the forty "faculty members" would count as professors in the ordinary sense. Then the so-called answer just shifts to a different topic altogether.

One would ordinarily take the marked change of topic to indicate that sufficient information has been supplied to find an answer to the question, but that is a presumption that cannot be redeemed. And the deeper one looks, the less clear it is that the memo means to implicate an answer at all. The first two sentences in this so-called "answer" do constitute some sort of oblique admission that not everyone teaching freshman composition is a professor. But even this is not clear. An unwary reader might well be gulled into thinking that the categories of faculty the memo does mention are professors. Undergraduates and the public at large are generally fuzzy about these distinctions. Still, this lack of

${ }^{17}$ Some persons who have been faculty at other institutions might there have been professors without an advanced degree. "Part-time faculty" can also include professors who once were regular professors and are now retired or have moved on to other occupations, and still like to pick up a course or two on the side.

(C) Scott Jacobs. Informal Logic, Vol. 36, No. 2 (2016), pp. 159-191. 
discernment is why the 60 Minutes story has some newsworthiness in the first place. The exposé calls attention to a distinction that undergraduates and the public ordinarily let pass. And the memo's third question and response only makes sense as addressing the implications of that distinction for teaching freshman composition.

A careful reader could infer as a kind of practical calculation that the reason why the memo uses slippery wording here is because in fact there are no professors teaching freshman composition. Still, the wording certainly does not go so far as to admit that there are no professors. As a practical calculation one could infer the reluctance to admit this is what motivates the abstruse wording (if it were false, the answer would have come out and said so as it did in the first two answers). But neither does the memo seem to implicate that because some are not professors, some are. There is a delicate balance struck that does not really tip either way. In fact, it turns out that there were not any professors teaching freshman composition at the University of Arizona, but I don't think you would want to say that this is what the memo means to communicate or that this is what the memo means to deny. Nor does the memo even mean to be taken as opting out of an answer, however indirectly. It seems to signal that it $\underline{i s}$ an answer even though it is not.

Here is the classic double-bind situation that motivates paradoxical messages like evasive answers (Bavelas 1983; Polcar \& Jacobs 1998). In such situations, there is no good answer. Not even no answer is a good answer. All are damaging-even appearing not to address the issue at hand is damaging. In any case, the important thing to see with this memo is that despite the fact that nothing is really being hidden, the casual reader is apt to miss that neither is anything really being revealed. The unwary reader simply presumes that an indirect answer is there to be found if they go to the trouble of looking for it.

\section{Radar detector ad}

An even more peculiar kind of fraud occurs in an advertisement for Escort and Passport radar detectors (Cincinnati Microwave 1989). Grice (1975) proposed the Cooperative Principle and Conversational Maxims and the idea of conversational implicatures as an account of how public meanings could extend beyond the code rules of syntax and semantics. It was an effort to show how an architecture of intersubjectivity could be based on rational inference concerning reflexive intentions-what Grice (1957/1989) termed non-natural meanings. While this is 
the focal centerpoint of message meaning, there is always also a penumbra of meaning that hovers between what is given (and seen as given) by the speaker and what is brought into the situational background and read into the message by the hearer. And in this outer range of meanings, there is no clear line distinguishing what is given off by the speaker and what is put in by the hearer. ${ }^{18}$ The methodological tension between fidelity and charity that worries argumentation analysts has an interpretive counterpart in natural language understanding. These uncertainties and indeterminacies of meaning give rise to mistakes and, not surprisingly, to strategic abuses that capitalize on these possibilities.

In this ad, we have something that leaks out far outside the Gricean prototype of reflexively intended communication and mutually accomplished intersubjectivity. We seem to find an argument in the offing, but not one offered. An argument is intuited to "be there" somewhere, but not in the text and not quite in the message. Neither did the speaker really make it, and barely alludes to it, if at all. And if the hearer becomes aware of the argument, there is no sense in which the argument is properly attributed to speaker or text, not even when the speaker could properly be said to expect the hearer to become aware of the argument. The argument isn't properly implicated, but its shadow hangs over what is argued, disguises its defects, and ultimately appropriates and refashions the import of the argument that is in the advertisement.

At the top of the advertisement is a picture of the view of highway traffic through the windshield of a patrol car with the radar speed display on the dashboard flashing a "43.". Beneath the picture in small print is the legend "Traffic radar doesn't say which car is being clocked, it merely flashes a number. The radar operator must then try to determine which vehicle produced the reading." Beneath this picture, centered across the page in bold block type reads the headline:

\section{Why radar makes mistakes. How to protect yourself.}

The ad copy consists of a three-column elaboration of this headline, closing with ordering information. The first column of

\footnotetext{
${ }^{18}$ The distinction between expressions given and information given off is Goffman's (1959, p. 2). Jacobs and Jackson (1982, pp. 211-218) elaborate implications for argumentation theory of the distinctions among strategic design, reciprocal perspective-taking, and reflexive intentions in communication. See also Kauffeld (2009) for a defense of Grice's notion of utterance meaning.
} 


\section{Scott Jacobs}

the advertisement alerts the reader to "the most common source of wrongful tickets" (See Figure 4). The column explains how traffic radar can lead police to mistakenly identify the driver whose speed registered on the radar screen. The problem is that radar detectors only register the speed of whatever vehicle reflects the strongest signal. But the screen does not identify which of the many vehicles is reflecting the signal. So, the traffic cop has to identify the speeder by looking out his windshield at all the oncoming and outgoing traffic. The cop can make a mistake. And an unlucky driver might be ticketed for speeding when it was actually someone else that the radar had picked up.

Although nine different errors have been documented for traffic radar, the most common source of wrongful tickets is mistaken identity. It's hard to believe, but traffic radar does not identify which vehicle is responsible for the speed being displayed. It shows only a speed number and nothing else. The radar operator must decide who is to blame.

\section{How radar works}

The radar gun is aimed at traffic and it transmits a beam of invisible waves. Each moving object within range reflects these invisible waves back to the radar gun. Using the Doppler principle, the radar calculates speed from the reflected waves.

\section{Traffic radar is blind}

Traffic radar works differently from military, air trafficcontrol, and weather radars. The others use rotating dish antennas in order to track many objects simultaneously. Traffic radar uses a far smaller, far cheaper, gun-shaped antenna. This simplification requires traffic radar to ignore all reflections but the strongest. The number displayed is speed calculated from the strongest reflection.

\section{The best guess}

Remember, these reflections are invisible. Truck reflections can be ten times stronger than car reflections. How can the operator know for sure which vehicle is responsible for the number? The truth is, he can't be sure in many cases. The result is mistaken identity. You can be ticketed for somebody else's reflection.

Figure 4. Why Radar Makes Mistakes. How to Protect Yourself [column one]

At the top of the center column is a section entitled "Self defense" (See Figure 5). Ostensibly, the desire to avoid such "wrongful tickets" is the reason why the reader should purchase an Escort or Passport radar detector. According to the ad, "The 
only way to defend yourself against these wrongful tickets is to know when radar is operating near you." And using one of these radar detectors while driving down the highway will let you know that. Even a judge "agrees with this method." The ad then goes on to detail the particularly good job these radar detectors do of warning the driver when they are under radar surveillance ("We can help"). As the ad claims, "Escort and Passport are the most effective radar-warning instruments available."

So, buy their radar detector.

\section{Self defense}

The only way to defend yourself against these wrongful tickets is to know when radar is operating near you. Others agree with this method. In his verdict upholding a citizen's right to use a radar detector, Judge Joseph Ryan, Superior Court, District of Columbia, wrote:

"If government seeks to use clandestine and furtive methods to monitor citizen actions, it can ill afford to complain should the citizen insist on a method to effect his right to know he is under such surveillance."

\section{We can help}

We specialize in radar warning. And Escort and Passport do far more than simply find radar. Upon radar contact, the alert lamp responds and the meter shows radar signal strength. At the same time you will hear an audio warning - pulsing slowly when the radar is weak, quicker as it strengthens, then constant as you approach close range. When you know exactly how strong the radar waves are, you'll know when the radar unit is near enough to actually have you under surveillance.

\section{Expert's Choice}

Escort and Passport are the most effective radar-warning instruments available. But don't take our word for it. Car and Driver, Popular Mechanics and Roundel magazines have each published independent tests of radar detectors. And each gave us the highest ratings. Just call us toll-free and we'll send reprints of the complete tests, not just excerpts or quotes.

Figure 5. Why Radar Makes Mistakes. How to Protect Yourself [column two]

Now, there is a clear problem with the reasoning in this ad. But my repeated informal polling of students in my upper-division argumentation classes indicates that most students never see any problem - even though I read out loud through the entire ad with them and each student has a copy of the ad to read back over by 


\section{Scott Jacobs}

themselves. In fact, there are two clear problems with the argument, and both involve kinds of non-sequitur.

First, the proposed plan of action doesn't solve the problem. Having a radar detector and knowing that traffic radar is operating nearby is not going to help any driver avoid mistaken identification as a speeder or avoid the ticket for speeding. If someone else is speeding and the traffic cop mistakenly thinks it is you, your knowing that the radar is active will not change the facts on the road one bit. What are you supposed to do? Tell the ticketing officer, 'I wasn't speeding, officer. I'm a careful driver. I had my radar detector on, so that I would know when I was being monitored. I saw that I was being monitored. And I was especially alert to observe the speed limit."? How so many students regularly miss this gap in the ad's reasoning is a real puzzle. ${ }^{19}$

Perhaps we can find a clue to what is going on by examining the second non sequitur. It can be found in the top paragraph entitled "Self-Defense" in the middle column. According to the advertisement, Judge Ryan's verdict "upholding a citizen's right to use a radar detector" agrees with this method to "defend yourself against these wrongful tickets." But the Judge's opinion has nothing to do with the efficacy of this method of "self defense":

If government seeks to use clandestine and furtive methods to monitor citizen actions, it can ill afford to complain should the citizen insist on a method to effect his right to know he is under such surveillance.

The judge's opinion does affirm "a citizen's right to use a radar detector." But the quoted opinion in no way "agrees" with "this method" as a means to avoid "wrongful tickets" from mistaken identification.

One begins to suspect something more than just a simple non-sequitur. One begins to suspect a kind of equivocation in the advertisement's reference to "wrongful tickets." It is as though we are invited to go back and take into account a different sense in which these tickets can be thought of as "wrongful." In this sense, the issue is not one of being incorrect, but immoral. It is as though we are invited to assume that

${ }^{19}$ The defective reasoning seems so obvious that newspaper columnist Stephen Chapman (1989) called anyone who bought a detector on the basis of this ad's argument "a moron." As a matter of fact, prosecutors commonly use the presence of a radar detector in the vehicle as evidence that the accused was in fact speeding (Falk \& Ross n.d.).

(C) Scott Jacobs. Informal Logic, Vol. 36, No. 2 (2016), pp. 159-191. 
speeding is okay, rightful even, and that ticketing anyone for speeding is what is wrongful.

The section on "self defense" is really an argument that wants to implicate that drivers have a right to use radar detectors to avoid tickets for speeding so that they can speed without getting caught. The whole argument about mistaken identification is phony. But nobody notices the problem because nobody reading an ad like this is really worried about getting caught for not speeding. The concern of any reader interested in buying a radar detector is with how to avoid getting caught for speeding and to justify the ethics of using a radar detector to do so. ${ }^{20}$ This ad speaks to that purpose of the reader, and the ad is understandably abstruse in its advocacy of that kind of a standpoint.

The reader is apt to pass by the literal illogic of the arguments in the ad because, from the pertinent frame of reference, this ad makes perfect sense. I think readers unwittingly make a kind of interpretive adjustment for the argument as a whole, something like the way that natural language users caught up in an argumentative digression wind up by the end focusing on topical relevancies disconnected from those that initiated the digression (Jacobs, Jackson, Stearns \& Hall 1991). Or perhaps the better analogy is to the way in which malapropisms are corrected for in interpretation (Davidson 1986). In the case of this ad, we know what argument the ad could or should have made. That argument and the standpoint it would support is lurking in the offing. It is what the reader is expecting, even looking for. Still, the ad does not make the argument that the reader should buy the radar detector so they can speed without getting a ticket. Nor does the ad argue that it is legitimate to speed. The ad avoids claiming that ticketing speeders is wrong. And nowhere does it argue that using radar to catch speeders is illegitimate. These are virtual standpoints waiting in a familiar background with arguments just waiting to be drawn upon (van Eemeren et al 1993, chap. 5). The actual

\footnotetext{
${ }^{20}$ For most readers, the quotation primarily addresses the ethics rather than the legality of using radar detectors. In the United States and Canada, radar detectors are prohibited for commercial vehicles in all states and provinces except Alberta and British Columbia. Radar detectors in passenger vehicles are allowed in the United States except for Virginia and the District of Columbia. Canada prohibits radar detectors in passenger vehicles in all provinces except Alberta, British Columbia, and Saskatchewan (AAA/CAA 2016). By quoting from a Superior Court decision, the ad can be heard as implicating that any such prohibition is illegitimate. But if the ad were targeting commercial drivers, one would think the picture of traffic through the police windshield would have one or more trucks. Nor would the ad single out trucks as the culprit behind radar reflections mistakenly attributed to cars.
} 


\section{Scott Jacobs}

argument that does get made in the text is a kind of tease, waiting for the knowing reader to refashion it for their own purposes. And it does further reinforce the potential buyer's attitude that speeding tickets are wrong in the first place. ${ }^{21}$ If the information provided doesn't prove what it purports to, nobody really cares because the information can be put to other use.

\section{Conclusion}

If argumentation's Prime Directive is to determine the truth of a proposition according to the force of the better argument and the force of the better argument alone, then how to design argumentation so as to best satisfy this directive is the central problem of argumentation theory. That design problem necessarily involves messages and the way we express and interpret messages using pragmatic principles of communication. Pragmatic principles of communication are biases. They are presumptions that give structure to communication and provide for its very possibility. I take it that this has already been well established by the last fifty years of research and theorizing on communication and language use. These principles are usefully thought of as principles of message design, and as such, as principles of argumentation design as well.

We do not merely reason with and from arguments; we reason to them. The principles by which we do this are more than mere regularities or convenient conventions. They amount to rational norms, norms that are of one piece with the norms of reasoning and disputational conduct with which argumentation analysts have been traditionally concerned. They are norms that can be exploited and abused-because we are a charitable species - but they are norms we could no more live without than we could live without the complex, intricate, and nuanced understandings that they produce in argumentative messages.

\footnotetext{
${ }^{21}$ The myriad technical defects of traffic radar furnishes a standard meme on countless websites (For popular examples, see Radar Roy 2016, and Atkinson 1995). The use of this information is generally twofold. First, radar mistakes are deployed as part of a general argument to prove that speeding tickets in general and radar enforcement in particular are illegitimate-so, the driver has every right to speed and to evade getting ticketed. Second, the information is often framed as an argument that works in traffic court.
} 


\section{References}

AAA/CAA. (2016). Radar detectors. United States and Canada. Digest of motor laws. [American Automobile Association / Canadian Automobile Association]. Retrieved from http://drivinglaws.aaa.com/tag/radar-detectors/

Akmajian, A., Demers, R. A., Farmer, A. K., \& Harnish, R. M. (2010). Linguistics: An introduction to language and communication $\left(6^{\text {th }}\right.$ ed.). Cambridge: MIT Press.

Atkinson, K. (1995). Avoiding the speeding tax. Reasonable Drivers Unanimous [website]. https://www.ibiblio.org/rdu/psptax.html

Bach, K. (1994). Conversational impliciture. Mind \& Language, 9, 124-162.

Bavelas, J. B. (1983). Situations that lead to disqualification. Human Communication Research, 9, 130-145.

Bitzer, L. F. (1959). Aristotle's enthymeme revisited. Quarterly Journal of Speech, 45, 399-408

Brown, P., \& Levinson, S. C. (1987). Politeness: Some universals in language usage (Reissue of 1978 chap. with new intro. \& bibliography] Cambridge: Cambridge University Press.

Buhmiller, E., \& Myers, S. L. (2001, November 15). Senior administration officials defend military tribunals for terrorist suspects. New York Times. Retrieved from

http://www.nytimes.com/2001/11/15/us/nation-challengedpresidential-order-senior-administration-officials-defend.html

Bush-Quayle '88. (1988). Revolving door. [Video]. [Presidential campaign committee]. Retrieved from https:/www.youtube.com/watch?v=PmwhdDv8VrM

Carston, R. (1988). Implicature, explicature, and truth-theoretic semantics. In R. Kempson, (Ed.), Mental representations: The interface between language and reality (pp. 155-181). Cambridge: Cambridge University Press.

Chapman, S. (1989, March 9). Radar detectors: The law-abiding driver's friend? Chicago Tribune. Retrieved from http://articles.chicagotribune.com/1989-0309/news/8903250393_1_radar-detectors-police-radar-trafficradar

Cicourel, A. V. (1970). Cognitive sociology. Glencoe, IL: Free Press.

Cincinnati Microwave. (1989, July). Why radar makes mistakes. How to protect yourself. Popular Science, 166(7), 5.

College Republican National Committee. (1988). Get out of jail free. Compliments of Michael Dukakis. [Political campaign card]. Copy in possession of author. 
Copi, I. M. (1953). Introduction to logic. New York: MacMillan.

Davidson, D. (1973a). Belief and the basis of meaning, Synthese, 27, 313-328.

Davidson, D. (1973b) Radical interpretation, Dialectica, 27, 313-328.

Davidson, D. (1974). On the very idea of a conceptual scheme. Proceedings and Addresses of the American Philosophical Association, 47, 5-20.

Davidson, D. (1986). A nice derangement of epitaphs. In R. Grandy \& R. Warner (Eds.), Philosophical grounds of rationality: Intentions, categories, ends (pp. 157-174). Oxford: Oxford University Press.

Davis, W. A. (1998). Implicature: Intention, convention, and principle in the failure of Gricean theory. Cambridge: Cambridge University Press.

van Eemeren, F. H. (1987). For reason's sake: Maximal argumentative analysis of discourse. In F. H. van Eemeren, R. Grootendorst, J. A. Blair, \& C. A. Willard (Eds.), Argumentation: Across the lines of discipline (pp. 201-216). Dordrecht-Holland: Foris.

van Eemeren, F. H. \& Grootendorst, R. (1982). Unexpressed premises: Part I. Journal of the American Forensic Association, 19, 97-106.

van Eemeren, F. H. \& Grootendorst, R. (1983). Unexpressed premises: Part II. Journal of the American Forensic Association, 19, 215-225.

van Eemeren, F. H. \& Grootendorst, R. (1984). Speech acts in argumentative discussions. A theoretical model for the analysis of discussions directed toward solving conflicts of opinion. Dordrecht-Holland: Foris.

van Eemeren, F. H. \& Grootendorst, R. (1992). Argumentation, communication, and fallacies: A pragma-dialectical perspective. Hillsdale, NJ: Erlbaum.

van Eemeren, F. H., Grootendorst, R., Jackson, S. \& Jacobs, S. (1993). Reconstructing argumentative discourse. Tuscaloosa: University of Alabama Press.

Falk \& Ross, PA. (n.d.) The legal issues with radar detectors and traffic violations. HG.org Legal Resources. Retrieved (2016, May 15) from:

https://www.hg.org/article.asp?id=24206

Frederking, R. E. (1996). Grice's maxims: "Do the right thing." In B. Di Eugenio, N. Green, J. Hirschberg, M. Walker, \& R. Young, (Eds.), Working notes of the AAAI-96 spring symposium on computational approaches to interpreting and gen- 
erating conversational implicature (pp. 21-26). Stanford University. Menlo Park, CA: AAAI Press.

Goffman, E. (1959). The presentation of self in everyday life. Garden City, NY: Anchor Books.

Govier, T. (2010). A practical study of argument ( $7^{\text {th }}$ ed.). Belmont, CA: Wadsworth.

Grice, H. P. (1957). Meaning. The Philosophical Review, 66, 377-388. [Reprinted in Studies in the way of words (pp. 213223)].

Grice, H. P. (1975). Logic and conversation. In P. Cole \& J. Morgan (Eds.), Syntax \& semantics, vol. 3: Speech acts (pp. 22-40). New York: Academic Press. [Reprinted in Studies in the way of words (pp. 22-40)].

Grice, H. P. (1989). Studies in the way of words. Cambridge: Harvard University Press.

Horn, L. (1984). Toward a new taxonomy for pragmatic inference: Q-based and R-based implicature. In D. Schiffrin (Ed.), Meaning, form, and use in context: Linguistic applications (GURT '84, pp. 11-42). Washington: Georgetown University Press.

Horwich, P. (1990). Truth. Oxford: Basil Blackwell.

Jackson, S. \& Jacobs, S. (1980) Structure of conversational argument: Pragmatic bases for the enthymeme. Quarterly Journal of Speech, 66, 251-265.

Jacobs, S. (1995). Implicatures and deception in the arguments of commercial advertising. In F. H. van Eemeren, R. Grootendorst, J. A. Blair, \& C. A. Willard (Eds.), Special fields and cases: Proceedings of the third ISSA conference on argumentation, vol. IV (pp. 579-592). Amsterdam: International Centre for the Study of Argumentation (SICSAT).

Jacobs, S. (2015). Les principes pragmatiques de communication dans l'argumentation, Argumentation et Analyse du Discours [En ligne], 15. URL: http://aad.revues.org/2078

Jacobs, S. (2016). Verbal swindles, frauds, and other forms of deceptive manipulation in the Bush Administration case for invading Iraq: How to exploit pragmatic principles of communication so as not to lie. In D. Mohammed \& M. Lewinski (Eds.), Argumentation and reasoned action: Proceedings of the $1^{\text {st }}$ European conference on argumentation, Lisbon, 2015, vol. II (pp. 553-567). London: College Publications.

Jacobs, S. \& Jackson, S. (1982). Conversational argument: A discourse analytic approach. In J. R. Cox \& C. A. Willard (eds.), Advances in argumentation theory and research (pp. 205-237). Carbondale \& Edwardsville: Southern Illinois University press. 
Jacobs, S. \& Jackson, S. (2006). Derailments of argumentation: It takes two to tango. In P. Houtlosser \& A. van Rees (Eds.), Considering Pragma-Dialectics: A festschrift for Frans $H$. van Eemeren on the occasion of his $60^{\text {th }}$ birthday (pp.121133). Mahwah, NJ: Erlbaum.

Jacobs, S., Jackson, S., Stearns, S. \& Hall, B. (1991). Digressions in argumentative discourse: Multiple goals, standing concerns, and implicatures. In K. Tracy (Ed.), Understanding face-to-face interaction: Issues linking goals and discourse (pp. 43-61). Hillsdale, NJ: Erlbaum.

Jamieson, K. H. (1992). Dirty politics: Deception, distraction, and democracy. Oxford: Oxford University Press.

Johnson, R. H. (1981). Charity begins at home: Some reflections on the principle of charity. Informal Logic Newsletter, 3(3), 4-9.

Johnson, R. H. \& Blair, J. A. (1994). Logical self-defense (U. S. ed.). New York: McGraw-Hill.

Kauffeld, F. J. (2009). Grice's analysis of utterance-meaning and Cicero's Catilinarian apostrophe. Argumentation, 23, 239-257.

Levinson, S. C. (2000). Presumptive meanings: The theory of generalized conversational implicature. Cambridge: MIT Press.

Lewis, D. (1974). Radical interpretation. Synthese, 27, 331-344.

Lewis, D. (1979). Scorekeeping in a language game. Journal of Philosophical Logic, 8, 339-359.

Mendelberg, T. (2001). The race card: Campaign strategy, implicit messages, and the norm of equality. Princeton: Princeton University Press.

National Security Political Action Committee. (1988). Bush and Dukakis on crime. [Video]. Retrieved from https://www.youtube.com/watch?v=cnxbRoHtiDE

National Security Political Action Committee. (1988). Cliff Barnes, Maryland. [Video]. Retrieved from https://www.youtube.com/watch? $\mathrm{v}=\mathrm{qm} 3 \mathrm{XTansvTs}$

Office of the President. (1995, March). Quick response to 60 Minutes. [Memo]. University of Arizona, Tucson. In possession of author.

Polcar, L. \& Jacobs, S. (1998). Evasive answers: Reframing multiple argumentative demands in political interviews. In J. F. Klumpp (ed.), Argument in a time of change: Definitions, frameworks, and critiques. Proceedings of the tenth NCA/AFA conference on argumentation (pp. 226-231). Annandale, VA: National Communication Association. 
Radar Roy. (2016). Mistakes of police radar. Did you know that over $25 \%$ of all citations are written in error? Radar Roy's OFFICIAL Radar Detector Review site! Retrieved from http://www.radardetector.org/radar-detector-info/mistakes-ofpolice-radar/

Recanati, F. (2012). Pragmatic enrichment. In G. Russell \& D. G. Fara (Eds.), The Routledge companion to philosophy of language (pp. 67-78). New York and London: Routledge.

Schutz, A. (1962). Collected papers I: The problem of social reality (M. Natanson, Ed.). The Hague: Nijhoff.

Schutz, A. \& Luckmann, T. (1989). The structures of the lifeworld, vol. II (R. M. Zaner \& D. J. Parent, Trans.). Evanston, IL: Northwestern University Press.

Scriven, M. (1976) Reasoning. New York: McGraw-Hill.

Simon, R. (1990, November 11). How a murderer and rapist became the Bush campaign's most valuable player. The Baltimore Sun. Retrieved from:

http://articles.baltimoresun.com/1990-11-

11/features/1990315149_1_willie-horton-fournier-michaeldukakis

Sperber, D. \& Wilson, D. (1995). Relevance: Communication and cognition ( $2^{\text {nd }}$ ed. with postface). Oxford: Blackwell.

Stahl, L. (1995, February 26). Get real. 60 Minutes. Season 27, episode 24. CBS News. Retrieved from: http://www.cbsnews.com/videos/get-real/

Thomas, S. N. (1973) Practical reasoning in natural language. Englewood Cliffs, NJ; Prentice Hall.

Thomas, S. N. (1991). Argument evaluation. Tampa, FL: Worthington.

Tiersma, P. (1990). The language of perjury: "Literal truth," ambiguity, and the false statement requirement. Southern California Law Review, 63, 373-431.

Walton, D. (2000). New dialectical rules for ambiguity. Informal Logic, 20, 261-274.

Woods, J. (2004). The death of argument: Fallacies in agentbased reasoning. Dordrecht-Holland: Kluwer.

Zipf, G. K. (1949). Human behavior and the principle of least effort. Cambridge: Addison-Wesley. 